Zanzibar indicate that pelagic fishes haunt the edges of the shallow marginal waters. The large research trawler of the Western African Fisheries Research Institute has made her first six trips, and a hundred species of fish were identified; the Institute has also started a study of the ecology and biochemistry of mangrove swamp.

The report of the Director of the Anti-locust Research Centre on locust research and control for 1951-52 refers to the resumption of investigations on the conditions affecting the incidence of flight and the speed and direction of swarm displacements following the reappearance of desert locust swarms in East Africa at the end of 1950. The type of flight performed by locusts is of importance in determining the rate of displacement, and sustained flight appears to require high humidities. Research activities of the Desert Locust Survey included the exploration of less known desert locust areas in Arabia, and studies on locust biometrics, hopper behaviour and ecology. Intensive work has been carried out on the ecology and population dynamics of the Moroccan locust in Cyprus, and the Desert Locust Control Organization based on Nairobi was strengthened during the year. Growing international co-operation is an encouraging feature of the present control campaign. A memoir on the desert locust in the Indo-Pakistani-Persian area is being edited for the press, and completes the series of memoirs dealing with generalized seasonal breeding and migration of swarms throughout the desert locust invasion area.

\section{FISHERIES RESEARCH IN BRITISH COLONIES}

$\mathrm{I}^{\mathrm{N}}$

MMEDIATELY after the Second World War an 1 extensive programme was set in motion under the Colonial Development and Welfare Act of 1945 to set up centres for fishery research in the British Colonies. It was realized that in fish there was a source of much-needed proteins which has scarcely been tapped. Of the research institutes to be developed the first to become established was that of the East African Fisheries Research Organization* at Jinja in Uganda under the directorship of Mr. R. S. A. Beauchamp. The publication of the Organization's annual report for 1951 affords evidence that the work of the Jinja laboratory is now beginning to bear fruit.

Research has been centred on Lake Victoria, and regular observations are showing how complicated are the conditions of a large tropical lake and how different they are from the classical picture supplied by the study of temperate lakes. The work is primarily aimed at finding out the economic possibilities of fishing, and to this end a study is being made of the fish populations, their food and ecology. With opportunities for regular observations over a number of years, it should be possible to answer outstanding questions on the growth and breeding of fish under tropical conditions. For this purpose a background knowledge of the conditions under which the fish live is essential, and investigations on the hydrology and algology are being made. Among results obtained to date, the possibilities of a new fishery for Mormyrids has been demonstrated; information has been gained about a number of fish

- East Africa High Commission: East African Fisheries Research Organization. Annual Report. 195i. Pp. ii +49. (Nairobi : Government Printer, 1952.) which will help towards assessment of the effects of fishing on their populations*; the ability of fish to digest different types of algæ has been shown, as well as the notable importance of insect larvæ as food. Among other practical aims is the study of molluses and the distribution of trematode parasites, especially Schistosoma.

But what is at once obvious from the report is the enormous and varied field for study, and the wealth of problems waiting to be solved in the teeming highspeed realm of tropical aquatic life. Many of these are fundamental questions which will need to be answered before the life-stories of the fish can be properly understood. In view of this it is most gratifying to note that visiting research workers from British and overseas universities are already finding their way to Jinja to work on their various private lines of research. In this way the work of the fisheries laboratory is advanced, and visitors and staff benefit enormously by mutual discussion and friendship. It is to be hoped that, when other laboratories are ready, more visiting research workers will seek the facilities they afford. The laboratory of the West African Research Organization at Freetown is reaching that stage.

F. S. RUSSELI

* Colonial Office. Fishery Publications, Vol. 1, No. 2 : Report on the Tilapia and other Fish and Fisheries of Lake Nyasa, 1945-47. By Rosemary H. Lowe. Pp. $\mathrm{x}+126+7$ plates. (London: H.M. Stationery Office, 1952.) 408. net.

\section{HUMBER LABORATORY FOR FISH RESEARCH}

A NEW laboratory for fish research, to be known as the Humber Laboratory, was opened in Kingston-on-Hull on December 5 by Sir Ben Lockspeiser, with Dr. Franklin Kidd, director of food investigation of the Department of Scientific and Industrial Research, in the chair. Some hundred representatives of all sections of the fish industry were present, as well as representatives of various official bodies. The new venture was heartily welcomed on behalf of the industry by Admiral Sir Robert Burnett, chairman of the White Fish Authority, and by Mr. J. Croft Baker, chairman of the British Trawlers' Federation.

The new laboratory is a sub-station of the Torry Research Station, Aberdeen, which since its inception in 1929 by the Department of Scientific and Industrial Research has been the base for practically all the research undertaken in Britain into the problems of the preservation of fish as food. Aberdeen has proved a most suitable centre for research owing to the close proximity of fishing grounds for supplying experimental material and the presence of the University and other local research institutes, particularly the Marine Laboratory of the Scottish Home Department. However, during the past twenty-five years the area habitually fished by British trawlers has extended to the regions of Bear Island and Spitsbergen, the Barents Sea and Greenland, and on occasion Newfoundland and the Davis Strait. Nearly three-fifths of the white fish brought to Britain during 1951 came from these distant waters. This distantwater fishing is concentrated on the Humber ports of Hull and Grimsby, which together accounted for more than three-quarters of the distant-water catch and just over three-fifths of Britain's total white-fish landings of more than eight hundred thousand tons. 
This was six times the quantity landed in Aberdeen, and was worth five times as much, namely, $£ 22$ million.

The distance of these prolific fisheries makes it more difficult to keep the catch in good condition on the voyage home, a journey that can take up to a week, after which inland distribution has still to be undertaken. In comparison, voyages to the nearer waters of the North Sea and Faroe Islands are much shorter and the catches much smaller. Since 1947 the Torry Research Station has been paying particular attention to the problems of improving the preservation of the distant-water catch, most of which consists of cod and haddock, and the establishment of the new Laboratory will provide a permanent base on the Humber which will make further work in this field much easier.

In opening the Laboratory, Sir Ben Lockspeiser pointed out that, of the three main sources of animal protein, meat and dairy produce have to be largely imported, much of it from dollar areas, while fish is mostly obtained by our own efforts. In consequence, it is rather surprising that although the British are consuming substantially less meat to-day than before the Second World War, they are, in fact, consuming per head less fish. Sir Ben gave as an example the kipper, a typically British product, of which, he said, the consumption is now only about half of what it was in 1947 and 1948. People will not eat fish willingly unless it reaches them in good condition, fresh or processed, and this raises questions of refrigeration, storage, smoking and canning. It would be wise to assume that Britain will have to rely increasingly on fish in the foreseeable future, and it becomes, therefore, more than ever important that the resources of fish, which are obtained with such cost in capital and labour and all too often in human life, should be husbanded. The Department of Scientific and Industrial Research, continued Sir Ben, is opening the new Laboratory on the Humber in the heart of the white-fish industry in order to help to come to grips with the practical problems of distantwater fishing. Industrial science is in the nature of a joint enterprise between industry and science. Although every now and then science takes a leap forward, creating a revolution in thought and practice, which it is vital for an industrial nation to recognize and take advantage of, more frequently advance is step by step, often in very small steps, every one of which has to be tested in practice. The Department of Scientific and Industrial Research attaches great importance to working in partnership with all sections of the industries it serves.

After the opening, visitors saw an exhibition of some of the results of recent work of Torry Research Station. The bacteriological problems of keeping fish fresh were illustrated, and an account was given of the methods used and results obtained in an extensive survey of the conditions of handling fish aboard distant-water trawlers, showing the temperature distribution in the fish holds and the loss of weight of fish during transport. Even with the most careful handling aboard ship, however, not all fish can be landed from the distant waters in a really fresh condition by the normal process of gutting, washing and icing. Another exhibit described work on the problems of preserving fish by freezing at sea, with samples of fish frozen in a new type of contact freezer now being developed for the purpose. The deleterious effects of the cold storage of fish at temperatures of $-10^{\circ}$ to $-15^{\circ} \mathrm{C}$. for a few months was demonstrated by contrast with the perfect condition of similar fish stowed at $-30^{\circ} \mathrm{C}$. for up to twelve months.

Various physical, chemical and engineering problems involved in the preservation of fish by smoking and drying were illustrated. Some demcnstrations were given of the recently developed humiditysensitive element which utilizes some electrical properties of anodized aluminium (see p. 177 of this issue). Several by-products of the fishing industry, and new methods of recovery, were described as well as current research on fish proteins, and work on fish skin being carried out at the Zoology Department of the University College of Hull for the Department of Scientific and Industrial Research.

The buildings for the new Humber Laboratory have been erected by the Ministry of Works and comprise four laboratories, a workshop, offices, a library, and space for handling, freezing and smoking fish on a semi-commercial scale. Altogether, this new establishment will function as an integral part of the Torry Research Station, providing facilities for workers from that Station as well as for its own as yet small staff, and continuing work on various fronts-for example, certain aspects of fish chilling, freezing, smoking and drying. It is hoped that, in addition to ad hoc problems, the programme will include basic biochemical and physicochemical studies in fish preservation.

\section{PROBLEM OF FUTURE WORLD FOOD SUPPLY}

$\mathrm{T}$ HE Nutrition Panel of the Food Group of the Society of Chemical Industry has arranged a series of meetings devoted to the subject "Food and the Future". The opening meeting of the series, under the title of "The Problem of Future World Food Supply", was held on December 10, with Dr. J. I. M. Jones in the chair.

Mr. F. Le Gros Clark spoke on the "Yardstick of Population" and posed the question, "Will there soon be too many of us ?", pointing to an eventual finite limit to the population that could be supported by the world. Famines have always been local and temporary, never of world dimensions, but the real cause for alarm is that no one can foresee in what precise corner of the world hunger may occur. Optimists, he said, believe that men, even after a long period of suffering, will learn to control their fecundity, while pessimists foresee only disaster.

Mr. Le Gros Clark traced the growth in population over the centuries, suggesting an eventual total of $8,000-12,000$ million before stability is reached. The problem of their food supply requires not mainly a technological transformation but a revolution in the habits of men and methods of farming - an agrarian revolution on a world-wide scale. The initiation of this revolution, he said, should have started fifty years ago, before the pressure of population had become so great. Nowadays, we cannot be excused because of ignorance, as perhaps could our grandfathers, who had less factual knowledge.

Most nations to-day, protested Mr. Le Gros Clark, are not giving the agricultural scientist and food chemist half the chance they should have of meeting the challenge. This is a matter for governments and people who move governments. The task before us, 